\title{
VIEW OF SECONDARY TECHNICAL SCHOOL STUDENTS ON THE PATHS AND BARRIERS TO THEIR PROFESSIONAL DEVELOPMENT
}

\author{
Dana Vicherková, \& Josef Malach \\ University of Ostrava; Faculty of Education, Department of Pedagogy and Andragogy \\ (Czech Republic)
}

\begin{abstract}
Students in the Czech Republic are increasingly interested in secondary school studies with a universal technical focus providing job security and a swift path to retraining according to existing labour market requirements.

The aim of the paper is to find out how Czech students of secondary technical schools evaluate their professional development in the course of their secondary school studies. Qualitatively oriented research is focused on the quality of development of the secondary school studies as regarded by the secondary technical school students in the Moravian-Silesian Region of the Czech Republic. The research outputs provide suggestions for students to improve their professional development throughout the secondary school studies, as well as suggestions for procedures that may help remove the occurrence of barriers in their educational paths to a technically oriented profession. A partial output of the research questionnaire survey is to describe, characterise and evaluate the idea of secondary technical schools' students about their future profession and the level of their motivation to study at Czech technical secondary schools.

Students consider the low number of teaching hours per week for teaching new modern technologies and computer-controlled machines to be a critical external barrier in their professional development. They admit low motivation to learn a large amount of theoretical information, without linking theory with practice. Practical work in workshops belongs among popular subjects.
\end{abstract}

Keywords: Professional development, students of secondary technical schools, barriers in educational paths, motivation to study, idea student's about profession.

\section{Introduction}

Critical views on the evaluation of factors influencing, both positively and negatively, the learning of the secondary technical school students in the Moravian-Silesian Region of the Czech Republic are the expressions of students' subjective opinions on the quality of teaching in terms of content and form, teaching conditions, processes related to teaching and professional practice, personal relationships in educational practice, motivational factors supporting students' interest in technology and other selected educational problems.

The problem of supports and barriers in the secondary education can also be reflected by the insight into the adult education as the secondary technical schools' students are the border group between the period of ending pubescence, when an individual creates their identity with an inevitable transition from the status of a child to an adult (adolescent) accompanied by a desire to become independent, to adjust their values, attitudes, goals. Secondary school students' self-concept is influenced by the desire to take specific patterns (e.g. from the family, extracurricular context) and the manifestation of anti-identifications, postponement of decisions, deeper socialisation, fluctuations in work or school performance, etc.

The study aims to point out the degree of readiness of the secondary school students for the further lifelong learning and entry into professional, technically oriented practice, and to find out how technical secondary school students evaluate professional development or its barriers during secondary school studies. 


\section{Support for education and lifelong learning}

Current trends of the education policy in the Czech Republic point to individuals' benefits from lifelong learning in various, e.g. economic, civic, social or technological, areas. Due to the formation and development of so-called human capital, we can talk about shifts in the economic development of current economies based on knowledge and competencies, e.g. according to the concept of Rizzo and Gallo (2012), Wawrocs and Heissler (2013). The need to educate social groups excluded from the labour market (unemployed, low-skilled) and regions affected by the decline of heavy industry, such as coal mining (which also includes the Moravian-Silesian Region in the Czech Republic), according to Eurydice (2015, pp. 8, 73). The European Union and the Ministry of Education, Youth and Sports of the Czech Republic emphasise the need to increase participation in the adult population's lifelong learning by $15 \%$. The removal of barriers to participation in education at secondary schools and universities and the promotion of interest in technology across age can help to achieve this ambitious goal.

\section{Paths to remove barriers in education}

Offering a diverse range of educational opportunities, regardless of age, is a way to eliminate indifference to education. Studies (Rabušicová, Rabušic \& Šed'ová, 2008) have pointed out the main trends in the occurrence of barriers in adult education. A case study (Kalenda \& Kočvarová, 2017, p. 71), based on research (Cross, 1981), pointed to the model of critical sociodemographic factors influencing the occurrence of barriers in contemporary Czech educational reality. Both studies emphasise three types of barriers to learning: situational, institutional, dispositional. Del Preto research (2013) focused on people without any interest in lifelong learning and identified the reasons for their demotivation for further education. An interesting outcome of the research is that "gender" is not one of the barriers to further education. Research by Rubenson (2010, p. 217) has pointed to an educational barrier related to the lack of time to learn. The adult population also shows a high workload in relation to a lack of interest in further study.

According to OECD (2011) and Kalenda and Kočvarová (2017), individual countries differ in the degree of perception of educational barriers. The Czech Republic is in the mid-range of the table according to the barrier rate (Desjardins \& Rubenson, 2013 and Kalenda \& Kočvarová, 2017, p. 74). Nordic European countries with a stronger motivation to learn are managing situational and dispositional barriers to lifelong learning most efficiently. A lack of influence of institutions with the characteristics of the "welfare state", as pointed out by structuring theory (Rubenson \& Desjardins, 2009) is persistent in the Czech Republic. A somewhat hybrid Czech model was identified by Vanhuysee (2006) and Kalenda and Kočvárová (2017, p. 74). The structure of barriers to lifelong learning in adults is relatively complex, containing situational, institutional and dispositional barriers. The results of the research (Rabušicová, Rabušic, \& Šed'ová, 2008, p. 105) explain the motivation of adults for education according to their relationship to it and the value respondents attach to it by identifying internal personality barriers (e.g. fear of failure, lack of purpose of further education) and external situational barriers (e.g. workload, health problems, many other interests) to motivation in formal and non-formal adult education. An interesting insight into the problem of students' self-evaluation as a particular effect of learning self-regulation and students' self-effectiveness was provided by research (Pandero, Jonsson \& Botella, 2017).

\section{Research methodology}

Data collection for the questionnaire research was carried out by members of the TAČR project, students of teaching and academics of the University of Ostrava in March 2020 - September 2020 who visited five selected secondary technical schools. The Technology Agency (TAČR) project is implemented by the Faculty of Education of the University of Ostrava and the Czech Machinery Cluster, the application guarantor. The TAČR project focuses on the support and innovation of education in engineering fields for the current labour market's needs. The research aimed to identify students' interest in the selected secondary technical school studies, stimuli, needs, and proposals to increase it further. The partial goal of the research conducted on 907 respondents (students of five secondary technical schools in Moravian-Silesian Region of the Czech Republic) was to identify barriers that may weaken students' initial interest in technology, engineering and new technologies and supporting factors of professional development through secondary technical school studies. For this paper, two open-ended questions were selected from the whole set of 41 items: (No. 29) What do you think could improve your professional development? (No. 30) What hinders you the most (which obstacles) in technical studies? We created 16 key categories (factors influencing the professional development of secondary technical school students) 
and 17 key categories (as obstacles in the professional development of secondary technical school students) by analysing the collected qualitative data at the level of open coding (axial and selective). They are presented in a graphic representation.

\subsection{Results}

What factors could improve the professional development of Czech students of secondary technical schools in the Moravian-Silesian Region? In the Czech context, we obtained the following results (see Graph 1). What barriers (obstacles) in professional development do the selected secondary technical schools' students in the Moravian-Silesian Region list? (see the graphical representation of results (see Graph 2) Regarding the factors influencing the professional development of students, the most frequently mentioned reason was "Increase in the number of hours of practice teaching $(20 \%$ of respondents) - the most strongly represented factor in the study support. Students (men) selected it across all years of study of secondary schools aged 15 to 19 . The second reason for supporting students' professional development was "more intense self-learning" (19\% of respondents) which related more frequently to students (men) aged 16 to 19 . The third reason for supporting development was "increasing the quality of teaching across subjects - theory and practice" (15\%). Respondents' answers include: "improve practice and vocational training", "have more intensive interaction with machines and equipment belonging to engineering", "more representation in theory and practice", "improve the diversity of the work in practice", "more experience and practice in the field". The fourth reason for supporting development was "better didactic, and professional skills/competencies of teachers" (8\% res.), chosen more frequently by students aged 17-19. Respondents' answers include: "better preparation of teachers", "more knowledge of teachers, discussions, better approach", "improve the innovative approach to teaching", "use of new terminology by teachers". The fifth reason for supporting development was the "change in the content of vocational education" (6\% res.) which applied to students across 15-19. From the list of respondents' answers: "see all parts of machines and be able to think about their function", "use of knowledge of the latest technologies", "to see more professional equipment with your own eyes, be able to touch it, connect theory with practice". The sixth reason for supporting development was "more excursions" (5\%) and "better organisation of teaching and better timetable $(5 \%)$. Both reasons were most frequently selected by students aged 17-18. Other student priorities of selected key supports for the professional development include "higher quality of curriculum interpretation" (4\%), "interest in technology, mechanical engineering" (3\%), "more intensive contact with the company" (3\%), "part-time job in the field of studies" (2\%), "higher quality of school aids" (2\%), "different choice of school" (2\%), "elimination of the pupil's own laziness" (2\%), "finances" (2\%), "higher motivation of teachers" (1\%). Among the barriers to professional development, students aged 15-19 most frequently chose "laziness" (19\%). Answers of students include: "I am lazy to learn", "laziness and comfort", "laziness and procrastination". The second obstacle in professional development was "lack of time" (19\% of respondents), which was most frequently mentioned by students (men) aged 16 - 17 years. Answers include, for example, "little time", "lack of time", "little time to study", "I do not have time to devote to school". The third obstacle to development was "other (unnecessary, non-technical) subjects" (10\%) selected by students aged 15 - 19. The rank of answers includes "unnecessary subjects", "many unnecessary subjects", "subjects that are not connected with the field of study". The fourth barrier to development was "school" (8\%), from the selected answers of the respondents we present "my school", "school and self-study", "studying at this school". The fifth obstacle to students' professional development is "poor teachers - low quality of teaching" (7\%), respondents' statements include "bad teachers", "poor didactic approach of some teachers", "annoying and lazy master in the workshop". The sixth - eighth barrier to development is "ways of teaching" (6\%). Some of the answers were "everything is very theoretical and I do not have the opportunity to try how it works", "speed of dictation by the teacher ", illogical system of explaining", "a lot of information at once", "insufficient explanation". Other barriers to development include "other interests" (6\%) and "little practice" (6\%). An alarming finding is that students consider "lack of interest in the field" (5\%) as an obstacle to development. Students stated: "during school I lost interest in the field", "lack of interest in studying the field", "lack of interest in the technical field ". A total of 5\% of students said that they were an obstacle to their development, a problem called "myself". Answers include "my clumsiness", "my brain", "my intelligence", "myself". A total of 19 pupils (3\%) consider the "quality of the curriculum" to be an obstacle to growth, such as "uninteresting topics", "information about cars that everyone knows", "lack of information". The twelfth obstacle to development is "I don't know how to do something", "I don't understand something" (3\%.), e.g. "because of the amount of theory I don't understand it", "sometimes I don't understand something", "I can't draw". Only $11(2 \%)$ students admitted the obstacle of "learning little". The following barriers to growth are: "inattention" (1\%), "classmates" (1\%), homework (1\%), health (1\%). Barriers: "transport", "money", "memory", "disruptive digital technologies" were identified in smaller numbers. 
Graph 1. Supports in the professional development as seen through the lens of students.

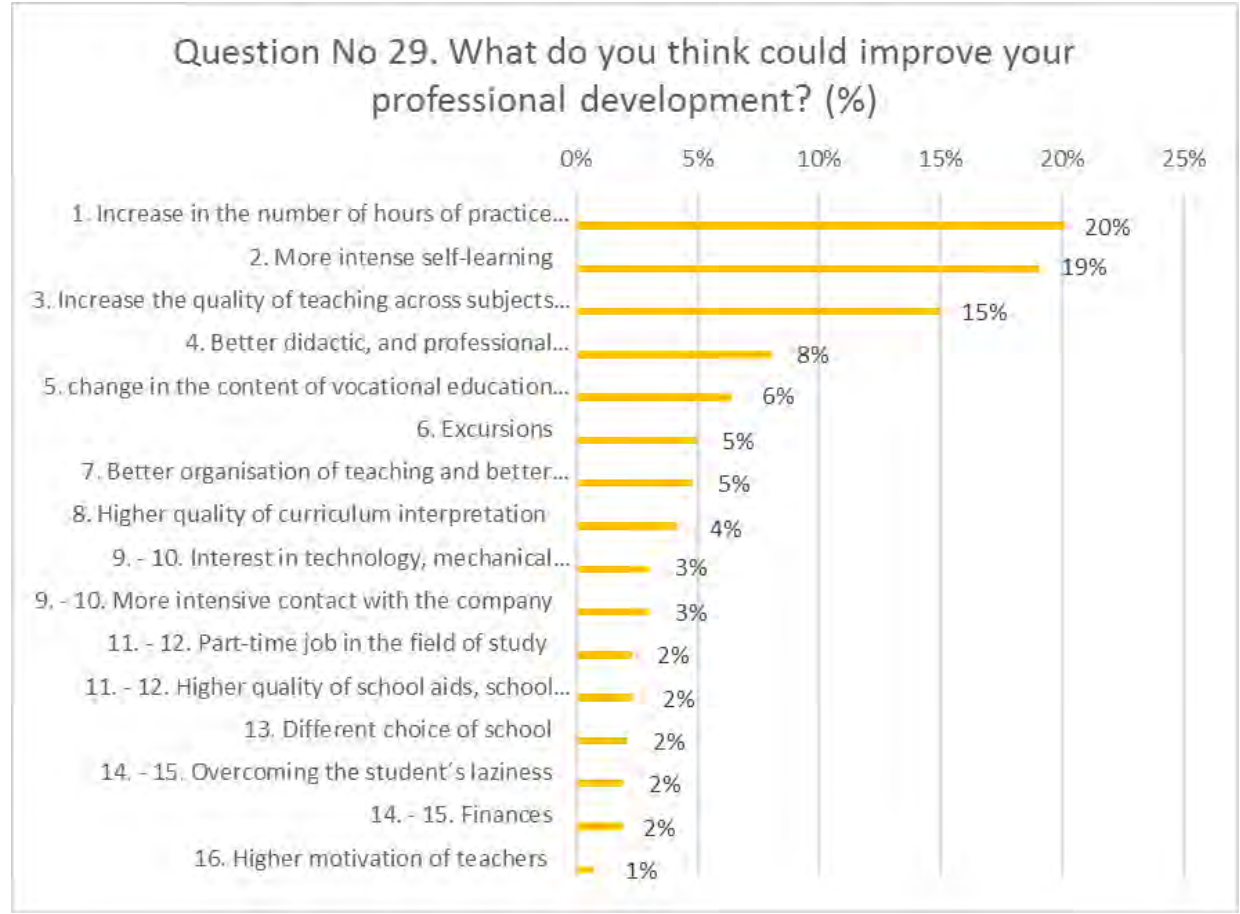

Graph 2. Barriers to the professional development as seen through the lens of students.

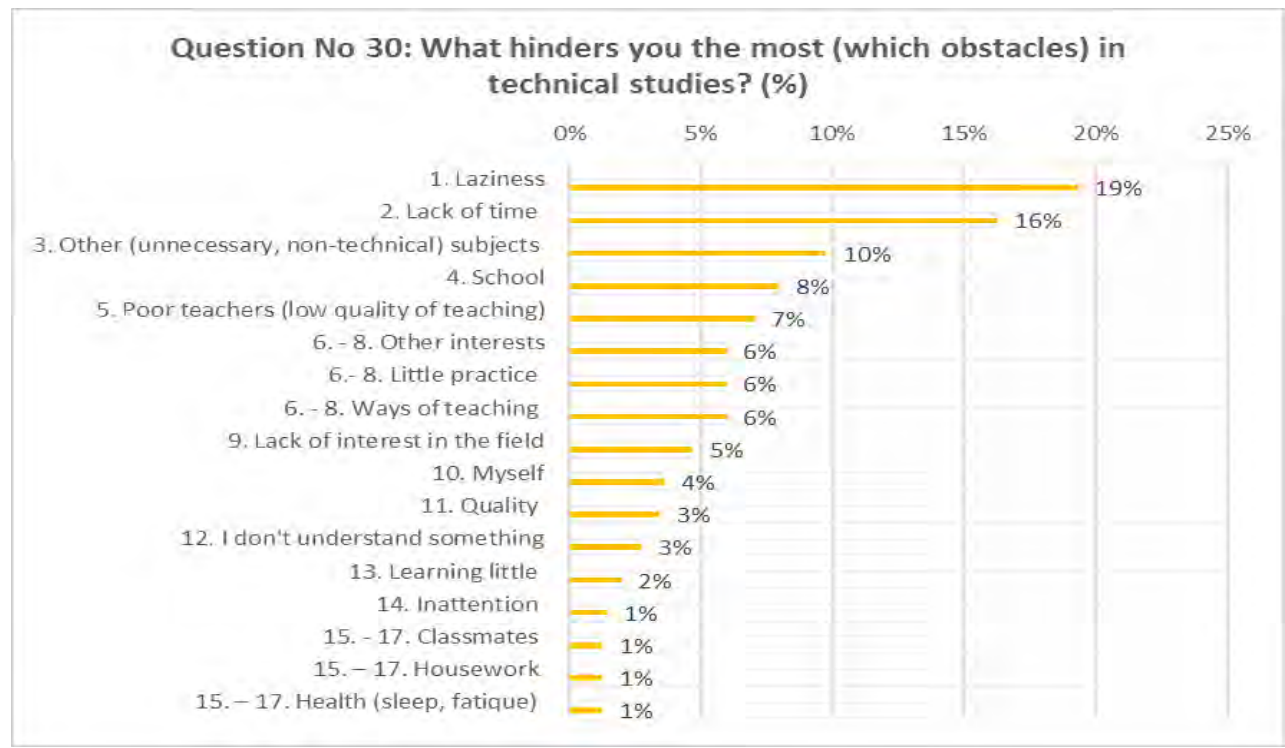

\section{Conclusion}

Students assessed difficulties (barriers) and supporting factors in professional development. Some respondents' answers were general, many students could not find a logical answer to the selected problem, and a third of respondents did not answer functionally correctly. The majority of respondents (561) were critical of the quality of their professional knowledge, skills, approaches to study the popularity of study, the field of study, the context of theory and practice in the teaching of technical secondary schools, problems related to classroom society and themselves, quality of content and forms of teaching, extracurricular interests, interest in technology and technical field, specific conditions of secondary school studies, the influence of family and home environment on studies, and other problem areas. Self-critically, the respondents commented on their laziness and lack of motivation to learn, inattention, lack of technical talent. Students consider the lack of quality professional practice and lower quality of professional subjects taught by outdated methods to be a key barrier in professional 
development. We understand pupils' self-reflection as one of the highest categories of assessment with an educational aspect. Through self-reflection, students can realise the stimulus for developing their personality, influencing their knowledge growth or obstacles in their professional procedural development. Important educational support for students' professional development is the school's effective pedagogical communication with the pupils' parents and the pupils themselves about barriers to learning and with an offer to develop plans for solving selected educational barriers (INEE, 2010, p. 88). Following the Dvořáková research (2016), we defined three types of barriers (situational, institutional, dispositional) in the access of adults (students of technical high schools) to education, in addition to personnel and curricular barriers.

\section{Acknowledgements}

This study was created as part of the research task of the Technology Agency of the Czech Republic entitled "Education in engineering and its optimisation for the needs of the labour market", ID TJ02000083.

\section{References}

Cross, P. K. (1981). Adults as learners. Increasing participation and facilitating learning. San Francisco:Jossey-Bass.

DelPreto, D. (2013). Students' voices: The live dexperience of faculty in civility as a barrierto professional formation in associate degree nursing education. Nurse Education Today,33(3), 286-290.

Desjardins, R., \& Rubenson, K. (2013). Participation patterns in adult education: The roleof institutions and public policy frame works in resolving coordination problems.European Journal of Education, $48(2), 262-280$.

Dvořáková, M. (2016). Andragogika v praxi. Odborný čtvrtetník pro vzdělávání a rozvoj dospělých 10/2016. Praha: AIVD ČR. [Dvorakova, M. (2016). Andragogy in practice. Professional quarterly for adult education and development 10/2016. Prague: AIVD CR.]

Eurydice (2015). Adult education and training in Europe. Widening access to learning opportunities.

Eurydice Report. Luxembourg: Publication Office of the European Union. Retrieved from http://eacea.ec.europa.eu/education/eurydice/documents/thematic_reports/179EN.pdf

INEE (2010). Minimum Standards for Education: Preparedness, Response, Recovery, s. 88. Retrieved from https://inee.org/standards.

Kalenda, J., \& Kočvarová, I. (2017). Proměny bariér ke vzdělávání dospělých v České republice. Studia paedagogica, vol. 22(3). [Kalenda, J., \& Kočvarová, I. (2017). Changes in barriers to adult education in the Czech Republic. Educational Studies, vol. 22(3).]

OECD (2011). Educationat a glance. Paris: OECD Publishing.

Panadero, E., Jonsson, A., \& Botella, J. (2017). Effects of self-assessment on self-regulated learning and self-efficacy: four meta-analyses. Educ. Res. Rev. 22, 74-98. doi:10.1016/j.edurev.2017.08.004.

Rabušicová, M., Rabušic, L., \& Šed’ová, K. (2008). Motivace a bariéry ve vzdělávání dospělých.In M. Rabušicová \& L. Rabušic (Eds.), Učíme se po celý život? O vzdělávání dospělých v Českérepublice (s. 97-112). Brno: Masarykova univerzita. [Rabušicová, M., Rabušic, L., \& Šed’ová, K. (2008). Motivation and barriers in adult education. In M. Rabušicová \& L. Rabušic (Eds.), Do We Learn Through Life? On adult education in the Czech Republic (pp. 97-112). Brno: Masaryk University.]

Rizzo, M., \& Gallo, A. (2012). Human capital and resources: Developments, management and strategies. New York: Nova Publishers.

Rubenson, K. (2010). Barriers to participation in adult education. In P. Peterson, E. Baker \& B. McGaw (Eds.), International encyclopedia of education (s. 234-239). London: Elsevier.

Švaříček, R., Šed’ová, K., Janík, T., Kaščák, O., Miková, M., ... Zounek, J. (2007). Kvalitativní výzkum v pedagogických vědách. Praha: Portál. [Švaříček, R., Šed’ová, K., Janík, T., Kaščák, O., Miková, M., ... Zounek, J. (2007). Qualitative research in pedagogice sciences. Prague: Portal.]

Vanhuysee, P. (2006). Czech Exceptionalism? A Comparative Political Economy Interpretationof Post-Communist Policy Pathways, 1989-2004. Czech Sociological Review, 42(6), 1115-1136.

Wawrocs, P., \& Heissler, H. (2013). Vybrané bariéry investic do lidského kapitálu. Naše společnost,11(1), 36-45. [Wawrocs, P., \& Heissler, H. (2013). Selected barriers to investment in human capital. Our society, 11(1), 36-45.] 